\title{
HARDSHIPS IN HUNGARIAN TERTIARY EDUCATION: THE ECONOMIC ROLE OF PRIVATE INTERNAL RATE OF RETURN IN ONLINE EDUCATION
}

\author{
Laszlo F. Mucsics \\ Karoly Robert College, Gyöngyös, Hungary \\ E-mail: mucsicsf@karolyrobert.hu
}

\begin{abstract}
The effects of global crises and the unique Hungarian economic difficulties render more and more hardships for non-full time students of higher education. The aim of this study twofold. It gives insight into how the ICTs are spread among the students of Karoly Robert College between 2006 and 2012 and examines the economic effect of private internal rate of return (IRR) by launching a form of online education in the changing environment of Hungarian tertiary education. In general, the study found that the student population is equipped with the proper up-to-date technology that enables using online education. In addition, with launching online education the students' private IRR may also be increased significantly by reducing the cost of indirect cost. With the technological inventions and applications of the 21st century the Karoly Robert College designs and introduces a new learning environment for nonfull time students since 2013.
\end{abstract}

Key words: e-education, structural reform, info-communication tools, private IRR to education.

\section{Introduction}

While governmental policy makers worldwide are strongly confronted with the amount of money invested into higher education (Tilak, 2006); the Hungarian government is unambiguously determined to decrease the investment in higher education. In 2012 the total public expenditure on higher education was one-third less than it was a year before and in 2013 another sharp decline follows. According to the government's Structural Reform Plan 2011-2014 (Széll Kálmán Plan) the reason for this inconvenient act is twofold. First, the Hungarian government is strongly determined to maintain the general government deficit below 3\% of GDP in 2012, 2013 and 2014. Second, "... the Hungarian education system is far from meeting the actual demands set by the economy and the labour market. We have been financing an education system with significant public resources that does not serve the interests of the economy, does not create value, and as a whole, increases public debt." (Ministry for National Economy, 2011) Norbert Kiss, the ex-deputy state secretary of education, also states that at present on half of the state-subsidized college or university students is further funded with grant scholarship often seemingly on the basis of subjective rights. (Kárász, 2012) As a consequence of reducing the normative financing, the present system of the Hungarian higher education is subjected to complete alteration, that is, "... in higher education, the development of the industries providing high added value would have required education of natural sciences and engineering to be more prevalent, since half of the trainings awarding diplomas were not based on market demands." (Polónyi, 2012) The statement suggests that awarding a natural science degree will 
OF EDUCA

PROBLEMS

IN THE $21^{\text {st }}$ CENTURY

Volume 53, 2013

experience more favourable opportunities compared to other type of degrees. This present governmental education policy intends to modify higher education fundamentally but lacking a general survey based balanced and sufficient funding, the Hungarian higher education system turns to be deformed soon and it will take decades to achieve the desired equilibrium. A question must be asked and answered: is the ongoing educational modification procedure a sort of optimisation or a damaging approach to cutting government expenses? The author delivers an economic approach to launching higher education degree courses in Hungarian higher education with technological devices such as m-learning, blended learning or e-learning. This way of learning may be a possible solution for those future students who found themselves in an everything-but-not-free education system and an economic system needing well trained employees in the workforce.

\section{Problem of Research}

What is the present situation like? In September 2012 the entry-level places getting full sponsorship fell to 33.000 (in 2011 this figure was 56.000). According to latest plans further cuts are going to take place in 2013, so the number of full sponsorships remains the same at best. As state-financed scholarships decrease and a great number of faculties have become or are becoming self-financed, a lot bigger percentage of future students are able to access public financial support in the form of loans. The Student Loan II (Széll Kálmán Plan 2.0) provides financial support for those who gained admission to non-financed higher educational programs. Hungary is entering the business of introducing student loans in bulk. As there is no survey or study it is impossible to predict the percentage of those who are deterred from entering higher education or obtain the Student Loan without knowing the possible consequences. In September 2012 Pew Research Center published some frightening figures on the demographic trends of student loans in the US; one of them is that one in every five households owes a student loan in the US. (Fry, 2012) Does Hungary, whose population is deeply buried in debt in foreign currency, really need to follow this path? As if the lack of financial cut was not enough, things are further complicated by the fact that state-financed students are to sign a contract obliging them to work in Hungary for twice the number of years they had spent in higher education. Changes in higher education are occurring far too fast and too dramatically, there is just one thing for sure: is not easy to be a graduate in a Hungarian high school today.

Although the present Hungarian government states that there is no tuition fee in Hungary, a significant percentage of future students will be forced to pay for their degree/educations. Possible reactions to the growing number of self-financed students can be different among Hungarian universities but most of them agree on offering online degree programs. Many pros and cons have been reported about the methodology of online, e-learning courses worldwide. Educational specialists write hundreds of articles for dozens of journals that deal with the educational methodology of e-learning. There might be heavy pedagogical debates on the advantages and disadvantages of e-learning applications but facts speak for themselves. In the US in 2003 approximately 500.000 students were earning degrees through online programs; in 2009 at least 5.6 million students were taking at least one online course during the fall 2009 term. And how does this global crisis influence the demand for online courses in the US? Three-quarters of the 2500 institutions reported that economic turndown has increased the demand for online courses and programmes (Allen \& Seaman, 2010).

Present circumstances in Hungary all call for launching online programmes by higher educational institutions. The educational policy of the government, effects of global crisis (e.g. rising unemployment, declining standard of living) and the technological achievements of the post dotcom era entrusts colleges and universities to offer graduate programmes. Why to do so? Because it is worth doing so. The total cost of developing e-learning education may vary 
Laszlo F. MUCSICS. Hardships in Hungarian Tertiary Education: The Economic Role of Private Internal Rate of Return in Online Education

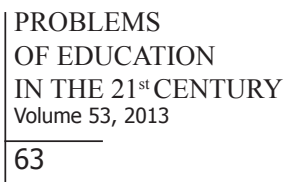

because of the topic or the structure or the course. The cost of an online multimedia or medical course with all interactive media elements may be very expensive while the simple bare-bones distance education may cost just a small fragment of it. As far as development costs are considered they can be grouped into three categories:

- Content development (planning, course consideration, management, content design (graphics) and writing, materials development, testing, final checking, evaluation, feedback).

- Infrastructure and technology (servers, networking, hardware tools, helpdesk service).

- Marketing expense (maintaining the previous two, advertisement, search engine placement).

When developing an online course these categories together take the majority of costs. A marginal cost is spent on maintenance. When measuring the cost of e-learning courses or programmes it is crucial to distinguish efficiency and cost effectiveness. (Mashal, 2008) For a fruitful online programme one does not go without the other. Cost effectiveness is usually examined by the cost comparison of per-student - enrolling in an E-learning and a traditional course (Minh, 2003). The next table shows that the cost per student in case of e-learning classes declines rapidly with the increases of class size. It declines faster compared to traditional education (Figure 1).

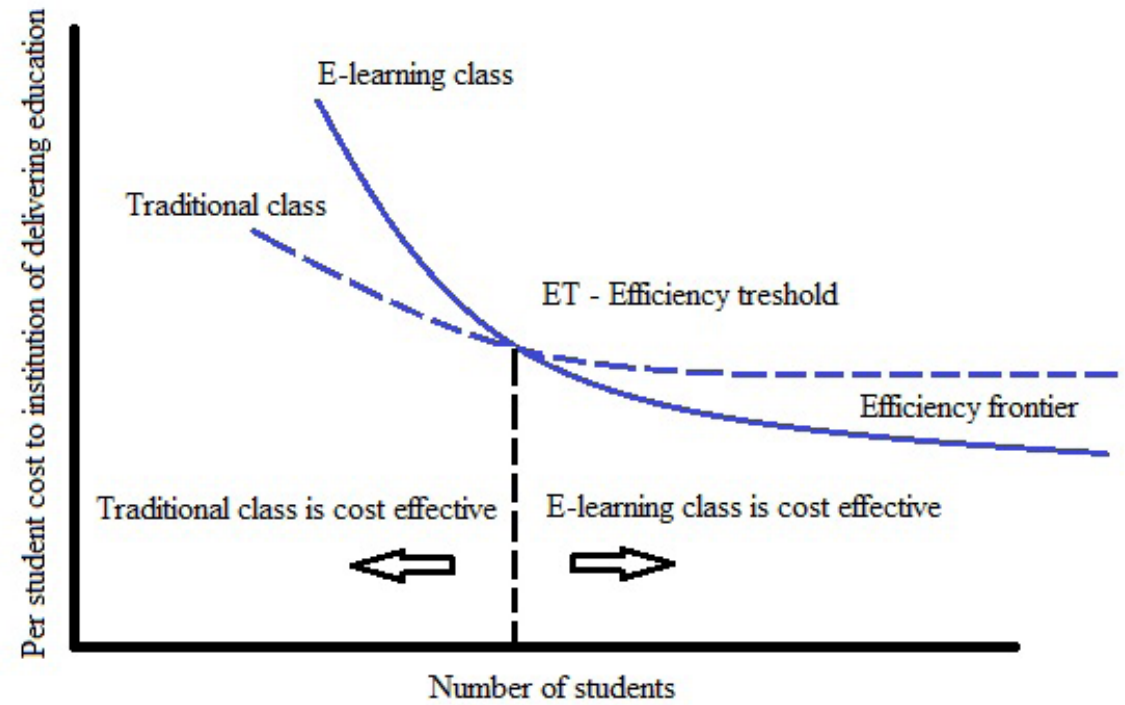

Figure 1: Per-student cost to institution of delivering education (based on Minh, 2003).

When the number of e-learning students is great enough - bigger than the Efficiency threshold needs - universities may find e-learning classes financially more fruitful than the traditional one. They may also be in the position of charging students for e-learning based courses even less, and that also induces massive interests from future students. Mention must be made that although this analysis is widely accepted, it is far too simple. As far as the management of two or three times as many e-students can be handled - just imagine the workload it provides for the instructor. 
Laszlo F. MUCSICS. Hardships in Hungarian Tertiary Education: The Economic Role of Private Internal Rate of Return in Online Education

OF EDUCATION

IN THE $21^{\text {st }}$ CENTURY

Volume 53, 2013

\section{Research Focus}

Higher educational institutions are forced to take steps to protect themselves against the disadvantageous circumstances created by the present Hungarian educational policy makers. Launching online educational courses or degree programs may be the solution for buffering against unfavourable governmental acts and this may also be beneficial for these institutions. The present study is carried out to achieve the following objectives 1) to obtain a baseline assessment of students' abilities and ICT backgrounds 2) to find out the reason(s) why students choose or do not choose online education and 3) to examine how the private IRR is changed when applying online teaching devices compared to traditional part-time teaching.

Are the future Hungarian students equipped with the necessary technological items (electronic devices, computer literacy, broadband Internet) (Part_1_Qs)? If yes, can the traditional correspondence (part-time) training be converted into this new form (online) of education? Is that new education format economically beneficial for the students (Part_2_Qs)?

Part_1_Q1_1: Is the infrastructure of info-communication tools suitable in Hungary?

Part_1_Q1_2: Is the infrastructure of info-communication tools suitable among the students of the Karoly Robert College (locally)? (What percentage of population is equipped with PCs, laptops or other M-learning devices?)

Part_1_Q2_1: Is the Internet accessibility suitable in Hungary?

Part_1_Q2_2: Is the Internet accessibility suitable among the students of KRF? (What is the trend like?)

Part_1_Q3: Are the students of the Karoly Robert College able to manage basic installation activities? (Computer literacy, computer knowledge)

Part_2_Q1: Why did not you choose the possibility of online learning? (17 students)

Part_2_Q2: Why did you choose the online attendance? (21 students)

Part_2_Q3: How much do you think you have saved with online attendance on Economic Mathematics I course instead of coming to campus? (3 events altogether)

\section{Methodology of Research}

The research consists of two studies. The first and the chronologically longer study examines students' ICT background (computer literacy, computer knowledge) ability locally (students of the Karoly Robert College) and globally (Central Statistical Bureau) between 2006 and 2012. The second study is carried out in semester 2012 Fall. Besides the traditional way of education the Karoly Robert College offered the optional possibility of online Economic Mathematics I course.

\section{The Sample and Profile of the Respondents (Study I)}

The sample of the first study consists of 514 students altogether between 2006 and 2012 . For six consecutive years the first-year part-time students of the Karoly Robert College were interviewed by a questionnaire (number of respondents 2007: 118, 2008: 116, 2009: 102, 2010: $86,2011: 54,2012: 38)$. The majority of the learners were female (74\%), older than $25(63 \%)$ and employed (86\%). 
The questionnaire is divided into 4 parts. The $1^{\text {st }}$ set contained questions concerning the students' personal particulars such as gender, age, employment, distance of learning centre from home, money spent on travelling, on catering while on campus, means of communication with the institution. The $2^{\text {nd }}$ group of questions examined the students' ability in using several computer applications (Word Processor, EXCEL, Learning Management Systems, Drupal, Moodle, NIIF Videoconference) and also measure the software installing ability of students using a 3-point scale: (1) I am professional; (2) I can do it with handbooks/sy's help; (3) I cannot do it. The $3^{\text {rd }}$ set of questions contained 15 questions to tease out the student's attitude towards the use of ICT in education and in everyday life (Internet availability, possessing ICT devices: PC, laptop, tablets). The $4^{\text {th }}$ set of questions contained questions concerning the opportunities that might be enhanced by ICT use (each electronic device must be evaluated by order of importance).

\section{Data Collection}

The questionnaires were distributed to students on the last occasion of their tutorial session each year. They were collected and processed using EXCEL. Thus the primary data (from the students) of this research is the result of a survey conducted by the author between 2006 and 2012 at Karoly Robert College among all first year part-time students. The primary data related to the student population studying at the Karoly Robert College at the time of the survey, thus all future consequences refer to the College and are not intended to create overall generalisations. For the secondary source of information the data of the Central Statistical Bureau (in Hungarian: Központi Statisztikai Hivatal, hereafter: KSH) is used. The method used is descriptive statistics that is quantitative descriptions of the basic data is provided with partition ratio.

\section{The Sample and Profile of the Respondents (Study II)}

The sample of the second study consisted of 38 learners who were the first-year part time students of the Karoly Robert College in 2012 Fall. The questionnaires were distributed to students on the end of the Economic Mathematics I course ( $3^{\text {rd }}$ occasion). The questionnaire is divided into 3 parts. The first set of questions referred to the students' age, gender, distance of college from home, way of travelling, cost and time of travelling. The second question (for on campus students, 17) and the third question (for online students, 21) were to figure out why the student chose online attendance or on campus attendance. This group (38) is referred to as the experimental group later on.

\section{Results of Research}

Part_1_Q1_1: Is the infrastructure of info-communication tools suitable in Hungary?

Hungary has achieved appropriate conditions for developing an information economy since the turn of the millennium due to the advanced mobile and fixed lined communications structure, and constant improvements in the availability of up-to-date information and communication devices in the household sector. The wide range of info-communication tools available in Hungary are reduced to PC ownership. According to KSH the PC possession shows a constant increase in the last 10 years (Figure 2). 
Laszlo F. MUCSICS. Hardships in Hungarian Tertiary Education: The Economic Role of Private Internal Rate of Return in Online Education

PROBLEMS

OF EDUCATION

IN THE $21^{\text {st }}$ CENTURY

Volume 53,2013

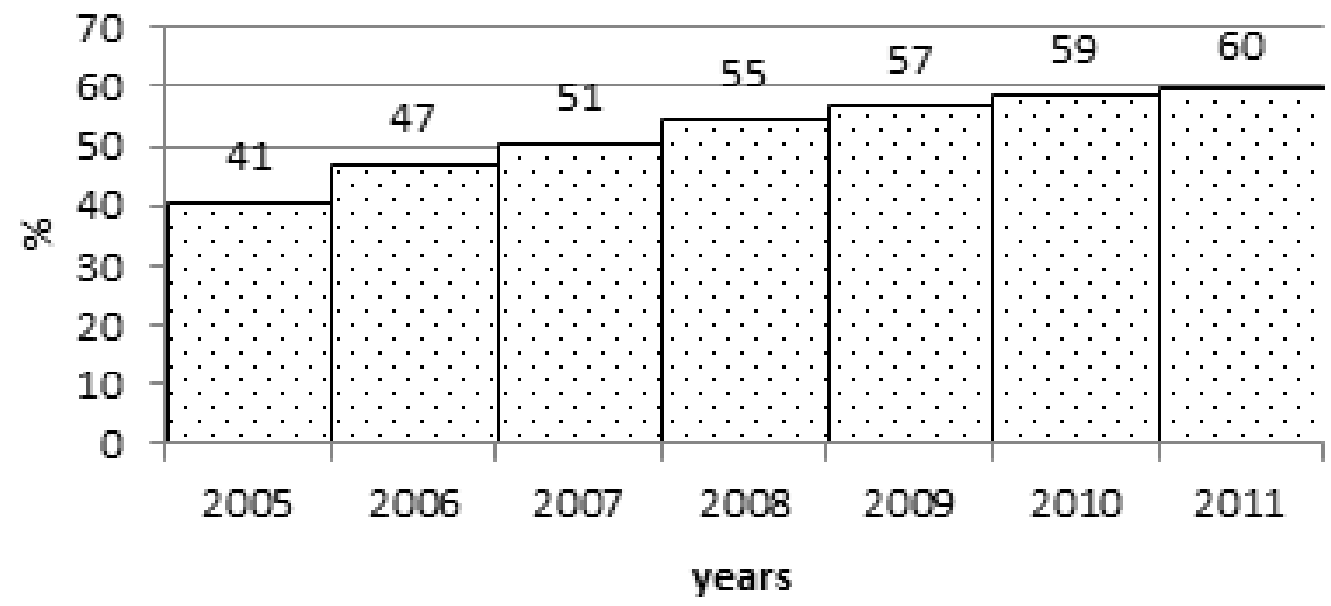

Figure 2: PC ownership in Hungary between 2005 and 2011 (source: KSH).

Mention must be made that the newest e-devices (laptops, tablets, smartphones, etc) appear as more and more challenging competitors to PCs and this may explain why the rate of PC ownership increases more slowly in the later years of the data. According to a prominent Hungarian computer magazine the need for tablets among households is higher than for laptops since August 2012 (Harangi, 2012).

Part_1_Q1_2: Is the infrastructure of info-communication tools suitable among the students of KRF?

The survey conducted among the freshmen of KRF shows an even more convincing impression. To the survey question "Do you possess at least one of the following electronic devices: PC, laptop, tablet?" the following table is developed (Figure 3):

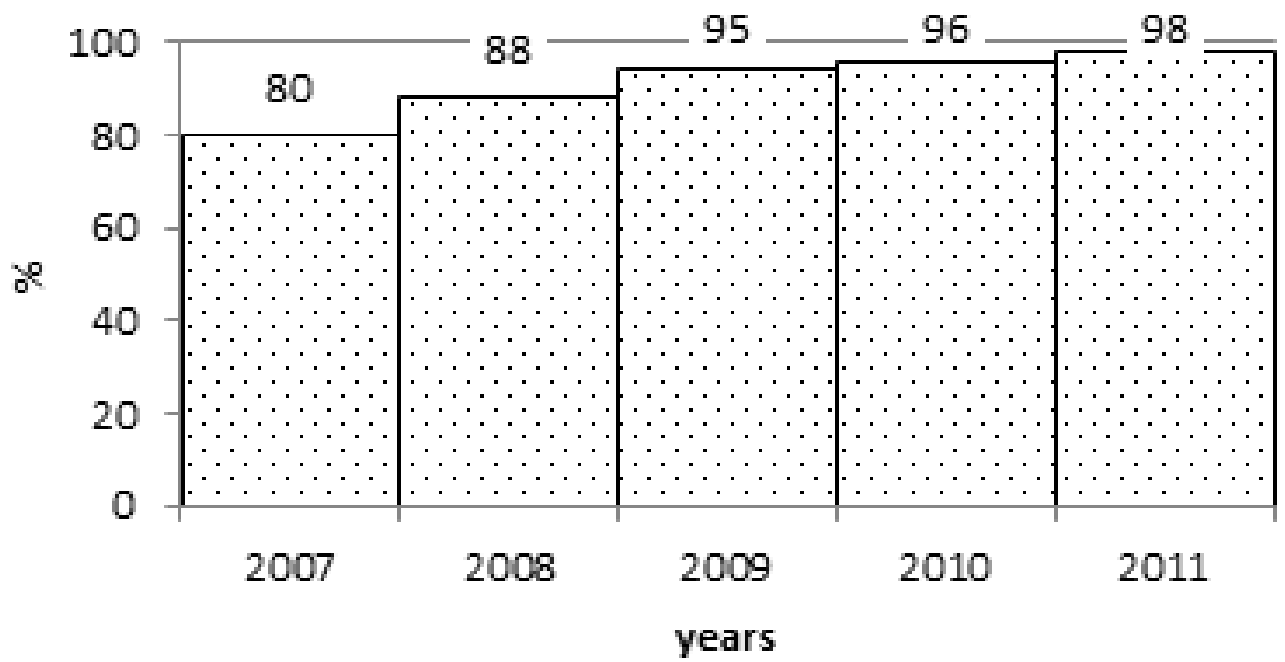

Figure 3: PC, laptop or tablet ownership among the students of Karoly Robert College (2007-2011). 
Laszlo F. MUCSICS. Hardships in Hungarian Tertiary Education: The Economic Role of Private Internal Rate of Return in Online Education

Shortage of technological devices among the students of KRF is not an issue. In 2011 almost all students are equipped with some electronic devices. The only person who does not possess any of the devices (in 2011) is a pensioner who carries on her education just for the love of learning.

Part_1_Q2_1: Is the Internet accessibility suitable in Hungary? (What is the trend?)

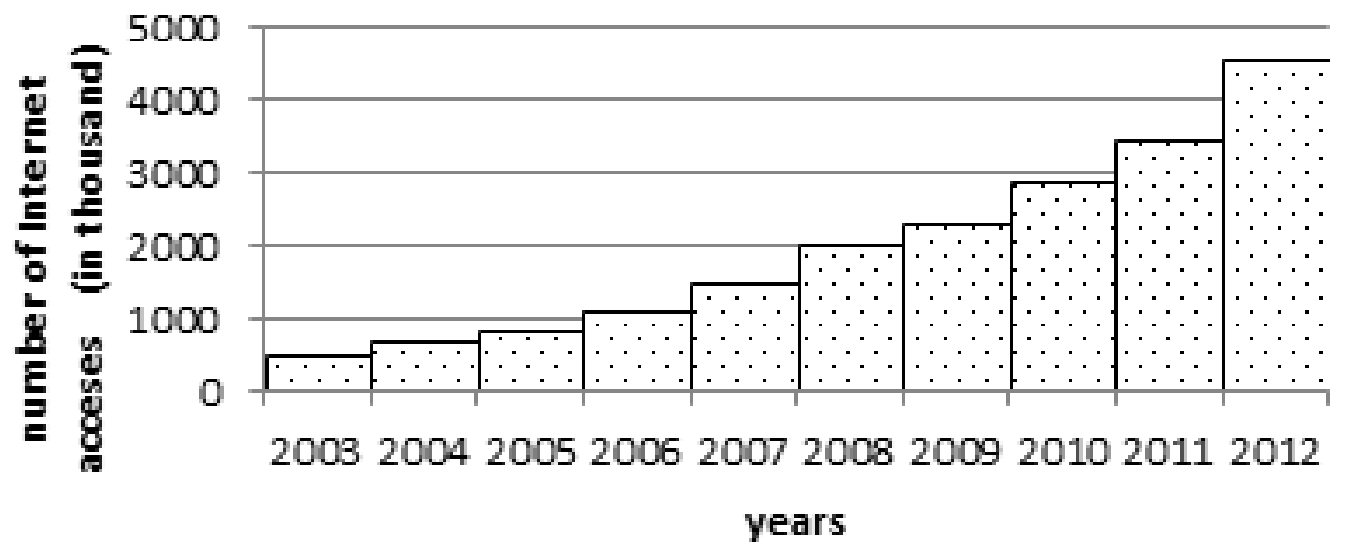

Figure 4: Number of Internet subscription between 2003 and 2012 in Hungary (source: KSH).

The rapid and dynamic progress in the number of Internet subscriptions (Figure 4) is due to the sharp price and technological competition among Internet providers. Mobile Internet usage has increased $60 \%$ by 2012 compared to the previous year as its price is becoming more and more affordable. The applicable trend is exponential

$$
y=419,62 \cdot e^{241 x} \quad r^{2}=0,9 .
$$

This result of the exponential growth means that the number of Internet subscriptions reached 4.3 million and today $65.3 \%$ of the Hungarian population (from infants to antediluvians) has Internet access.

Part_1_Q2_2: Is the Internet accessibility suitable among the students of KRF?

To survey question "Do you have broadband Internet access in your home? (not mobile)" the next table is presented (Figure 5).

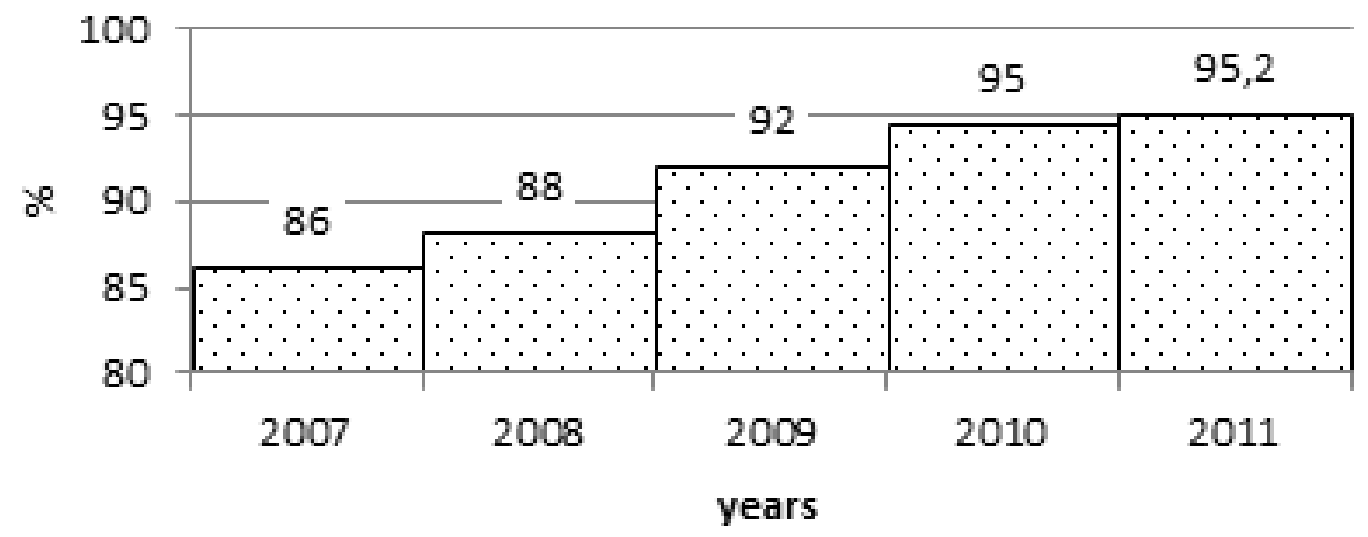

Figure 5: Percentage of Internet subscribers for first year students of KRF. 
Laszlo F. MUCSICS. Hardships in Hungarian Tertiary Education: The Economic Role of Private Internal Rate of Return in Online Education

PROBLEMS

OF EDUCATION

IN THE $21^{\text {st }}$ CENTURY

Volume 53,2013

68

Almost all students at KRF possess Internet access in their homes. The rapid and massive growth of information communication tools and broadband Internet both globally in Hungary and locally at KRF give grounds/basis to talking about the implementation of new learning environments.

Part_1_Q3: Are the students of KRF able to manage basic installation activity? (Computer literacy, computer knowledge)

Suitable level of electronic devices provides only one segment of e-learning education. Computer knowledge (usage of text editors, installing different software applications) of future students also plays a significant role when launching and designing a relatively new way of educational environment. To survey question "Are you capable of installing a software program individually with the help of an install book?" the next chart is given.

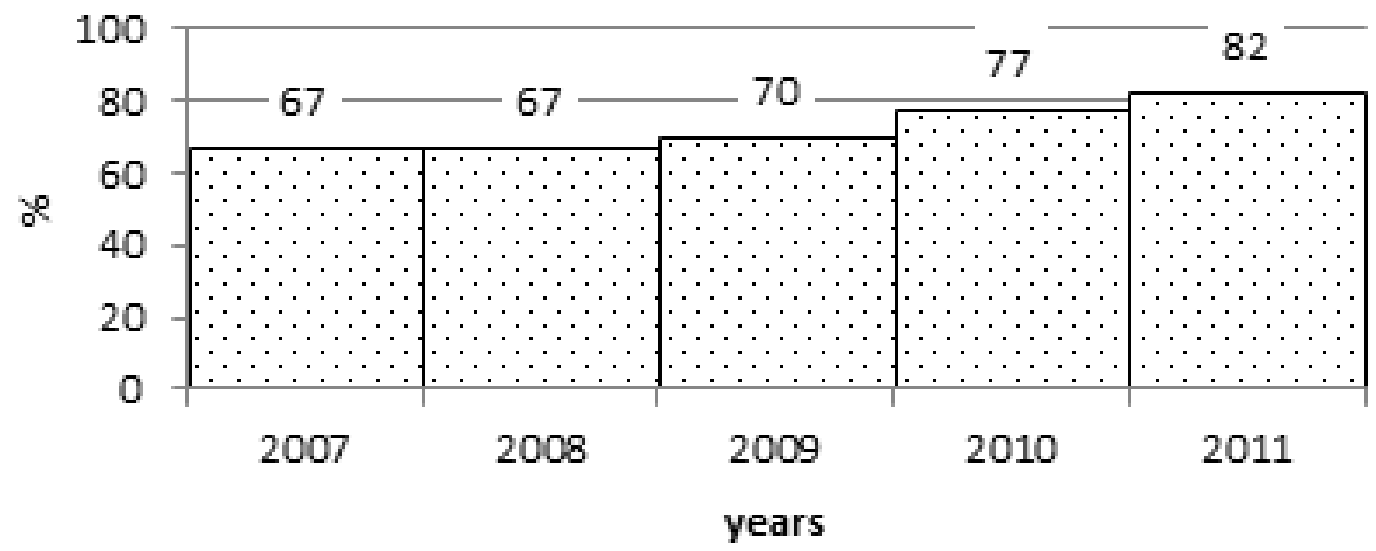

\section{Figure 6: Percentage of students who are able to handle with installation among the students of KRF.}

Percentages of from this chart (Figure 6) are lower than in the previous cases. Although growth can be observed, a significant percentage $(\sim 20 \%)$ of present students is not able install software. Improving students' technological skills related to detail-oriented descriptions of technical issues are required before switching them into e-education from the traditional one. A temporary transitional support is needed to provide help for students in need.

Technological competencies (info-communication tools, broadband Internet, computer knowledge) have been examined so far and the results suggest that the devices available in the early 21 st century are enabling agents for launching e-education in higher education. Technology can create new possibilities; however technology alone cannot ensure success. To achieve the success of e-higher education all criteria of ecosystematic view of education must be understood. What is the ecosystematic view of education? It is the mixture of technology, content, pedagogy and value (Kim, 2012). Focusing only one of these components while launching a new educational model would not lead to successful outcomes. The presence of info-communication devices has been examined so far; and the 21 st century abounds with different educational technology solutions. Karoly Robert College has been using Moodle, Learning Management system since October, 2005. At present, the College offers approximately 100 web-facilitated/ blended learning courses for students. Many program development companies appear with educational technology solutions that sell on the market of e-education but the focus must be on effective education technology that can sustain. However, sustainability is crucial in the case 
of launching a new educational model; this paper does not intend to deal with this issue. The pedagogical aspects of the educational technology Moodle have already been examined by the author (Mucsics, 2009). The first set of questions and answers provided positive feedback on available technology and technological devices. It allows continuing with an economic analysis by focusing on the students' cost-benefit efficiency of the e-learning education. One of the available methods of examining cost effectiveness is the Internal Rate of Return (IRR) to education. It is a standard measure of the profitability of undertaking additional years of schooling. The private rates of returns of the 1) traditional tertiary education and 2) the e-learning tertiary education are being analysed. The starting point is that in human capital theory schooling is comprehended as an optimising investment decision (Becker, 1967). The basic notion is that higher education is supposed to increase the productivity of the individual, that is, more skilled individuals are paid higher salaries. How long are the individuals supposed to invest in extra education? Logically, the investment should continue to the point where the present value of expected future earnings from extra schooling is equal to its sum of all direct and indirect costs. The applied method for calculating the balance of costs and benefits for individuals is as follows (Varga, 1998):

$$
\sum_{t=j+1}^{n} \frac{\left(W_{h}-W_{h-1}\right)_{t}}{(1+r)^{t}}=\sum_{t=1}^{j} \frac{\left(W_{h-1}+C_{h}\right)_{t}}{(1+r)^{t}}
$$

with: $h$ is a given level of education,

$h-1$ is the previous level of education, $W_{h}$ and $W_{h-1}$ are the wages of the given levels of education, $C_{h}$ is the cost of obtaining the $h$ level of education, $n$ is a number of working years, $j$ is the number of years needed to accomplish $h$ education, $t$ is for time, $r$ is for IRR to education.

The task is to find $r$ (rate of return) that makes the two sides (left: additional income, right: cost of extra edu- cation) equal. Before comparing the traditional versus e-learning forms of education some explanation and later correction need to be added to the 'costs' side (right side of the equation). It supposes that during the years of learning the individual suspends his/her employment, that's why $W_{h-1}$ is placed in the nominator of the (costs) fraction serving as the missing income (opportunity cost). Should that really be there? In part-time teaching there is one thing that is constant through several consecutive semesters, and this is the time of exams. Students insist on having exams on the weekends. When conducting the survey I also placed questions referring to why it is important to have the exam on weekends. The answer was thought-provoking: at least $74 \%$ of the respondents (for each academic year between 2006 and 2012) are employed while studying. If they are the majority, then the IRR to education should be modified to this:

$$
\sum_{t=j+1}^{n} \frac{\left(W_{h}-W_{h-1}\right)_{t}}{(1+r)^{\prime}}=\sum_{t=1}^{j} \frac{\left(C_{h}\right)_{t}}{(1+r)^{\prime}}
$$

Another immense alteration occurred to the years of $1990 \mathrm{~s}$, it is the introduction of tuition fees in Hungary. While in the 1990s after admission the Hungarian higher education was free of charge, today more than half of the part-time university students pay for their education. It means that the cost of education can be divided into two parts direct costs (e.g. tuition fee, admission fee, books and equipment fees) and indirect costs (e.g. travel, accommodation). Instead of using $C_{h}$ for the cost of accomplishing $h$ education I suggest dividing it into $C_{\text {direct }}$ 
Laszlo F. MUCSICS. Hardships in Hungarian Tertiary Education: The Economic Role of Private Internal Rate of Return in Online Education

OF EDUCAT

IN THE $21^{\text {st }}$ CENTURY

Volume 53,2013

and $C_{\text {indirect }}$ costs:

$$
\sum_{t=j+1}^{n} \frac{\left(W_{h}-W_{h-1}\right)_{t}}{(1+r)^{\prime}}=\sum_{t=1}^{j} \frac{\left(C_{h_{-} \text {direct }}+C_{h_{\text {indirect }}}\right)_{t}}{(1+r)^{\zeta}}
$$

If the $C_{h \text { indirect }}$ can or could be reduced by launching a new educational design (distance educa- $\quad$ tion), it means that the value of $r$ must increase, thus providing higher profitability for investing into education for the indi- vidual. The question is to what extent the $C_{h \text { indirect }}$ can be reduced. What is the percentage of the possible reduction compared to the sum of all cost? I figured out this number by an experiment that followed the 6-year-long survey.

The experiment students' group of the research was the first year part-time (non-campus) students of the 2012-13 academic years. This group of students (38 members) is required to take part physically in consultation hours during the semester that usually takes place at weekends. In one semester they have to complete 7 courses and each course requires 3 contact occasions. It means that these students come to Karoly Robert College 21 times in one semester ${ }^{1}$. One of the 7 courses is Economic Mathematics I. In this course the lecturer (and this case: the author) meets the part time students three consecutive Saturdays during the semester. The experiment was that a videoconference system ${ }^{2}$ was applied as an alternative possibility to take part the Economic Mathematics I course. 21 students out of 38 used this technology and no installation or technological problems were detected among them while preparing for the online contact. During the actual teaching activity no online contact was broken; the visual and voice transmission worked properly. The conference system also allowed the online students to ask questions and share opinions thus making the educational process collaborative.

All the 38 students were interviewed after accomplishing the course. The author was eager to know why the 21 students chose the form of online teaching and why the other $17 \mathrm{did}$ not. The rest of the questions concerned the online students.

Part_2_Q1: Why did not you choose the possibility of online learning? (17 students)

The answer sheer covered different possible answers but it also offered to give individual reason(s). More than one answer could be tickled (Figure 7).

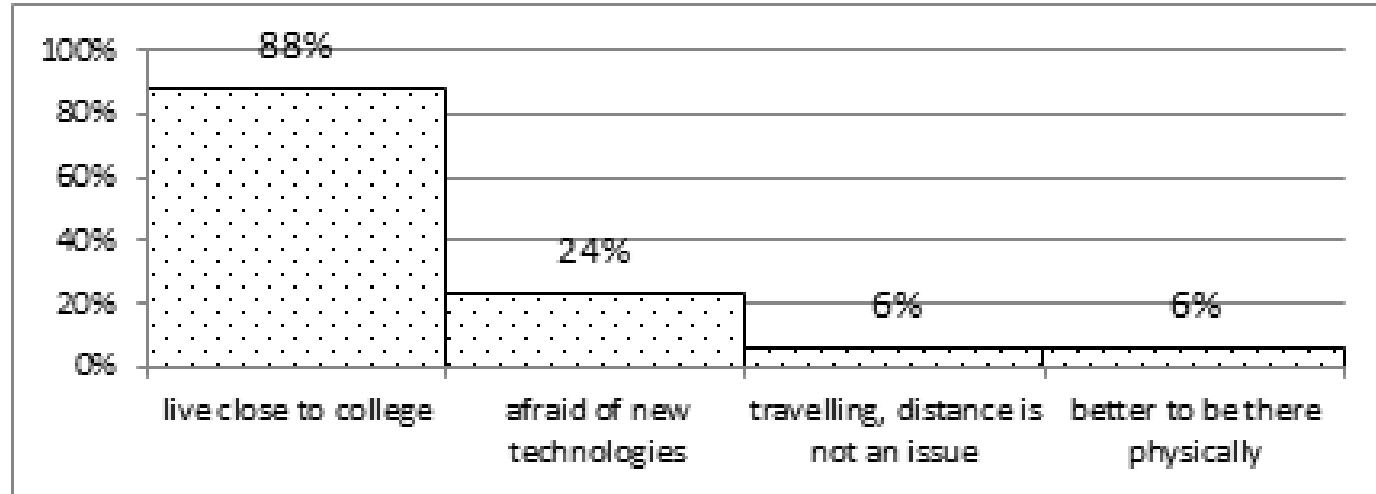

Figure 7: Reasons why NOT taking the online course.

1 The actual number is higher as each course ends with a verbal or written exam hosted at Karoly Robert College.

2 NIIF serves as a framework for the development and operation of the network in Hungary, the program covers an integrated computer networking infrastructure 
Laszlo F. MUCSICS. Hardships in Hungarian Tertiary Education: The Economic Role of Private Internal Rate of Return in Online Education

The answer 'live close to college' is surpassingly high that also means that the cost of travelling is not substantial and visiting the campus is not straining.

Part_2_Q2: Why did you choose the online attendance? (21 students)

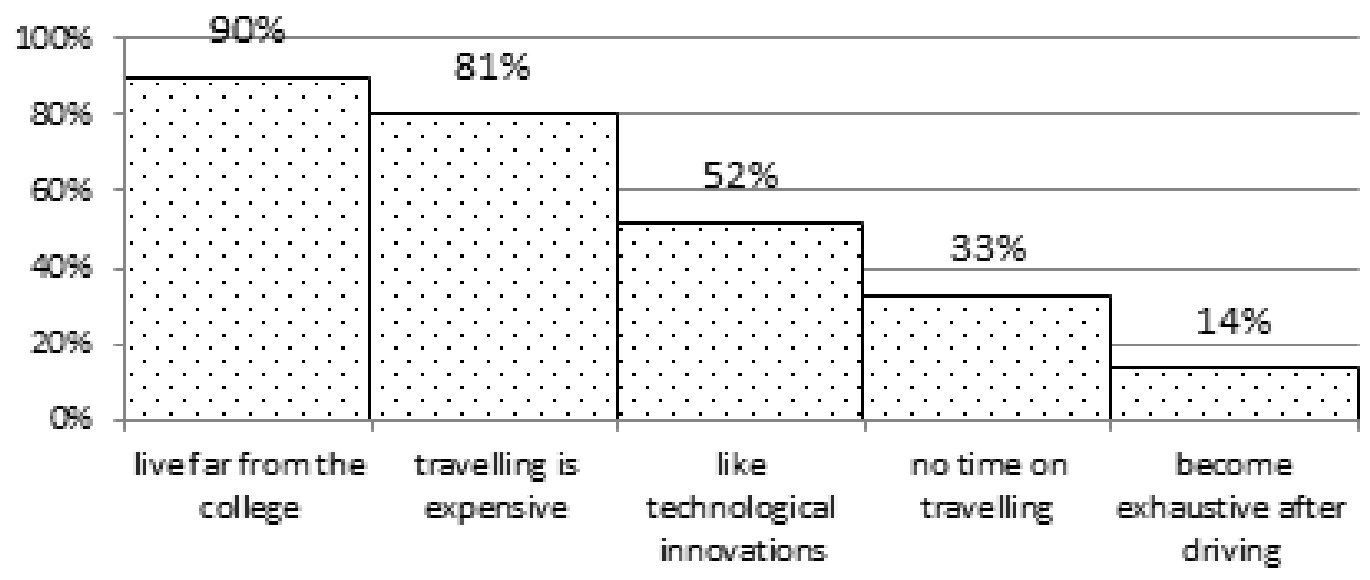

Figure 8: Reasons why taking the online course.

It can be clearly seen that the travelling distance and travelling cost are determining factors in choosing the online attendance (Figure 8).

Part_2_Q3: How much do you think you have saved with online attendance on Economic Mathematics I course instead of coming to campus? (3 events altogether)

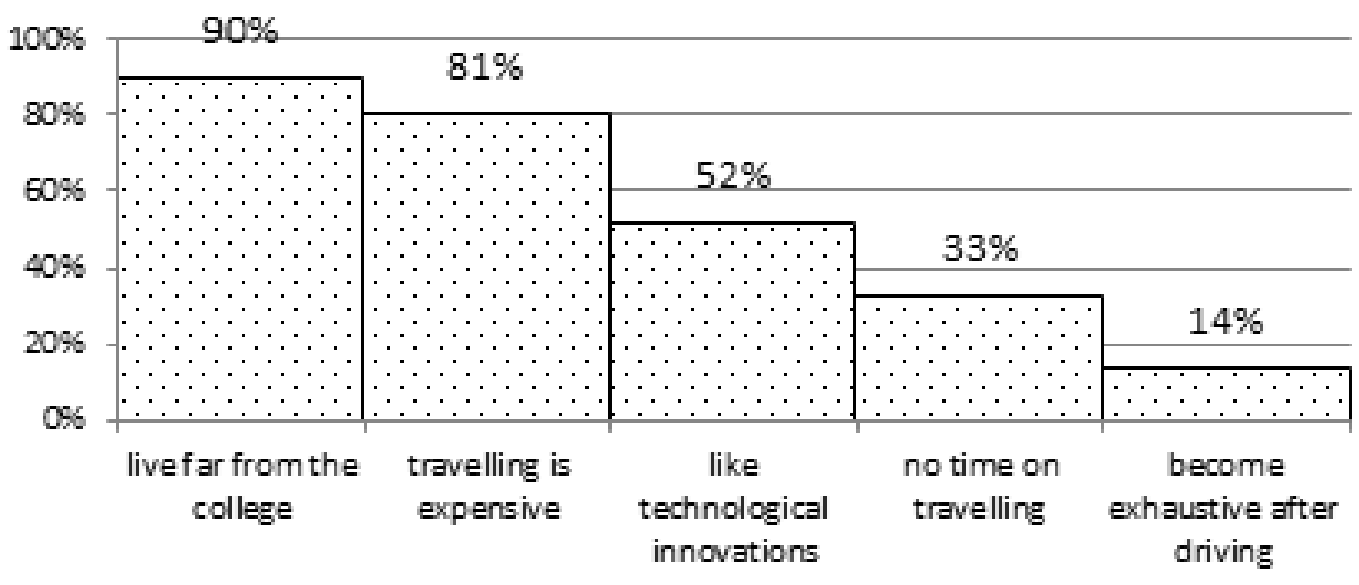

Figure 9: Distribution of savings in \% among online students.

The vast majority of the online students $(76,2 \%)$ saved more than 20,000 HUFs $(=100$ US\$) (Figure 9). How big is this amount of money compared to the amount of money students are required to pay for their education? The Karoly Robert College offers several BSc courses and the cheapest tuition fee is 150,000 HUFs (=750 US\$) per semester and students may choose to option of paying monthly. Credit-based tuition is applied only in full time education. As a semester lasts for 5 months, students are required to pay 30,000 HUFs monthly (=150 US\$). The number of compulsory courses varies from semester to semester but students are expected to accomplish at least 7 in each semester. Each course has compulsory attendance two or three 
Laszlo F. MUCSICS. Hardships in Hungarian Tertiary Education: The Economic Role of Private Internal Rate of Return in Online Education

OF EDUCATIO

THE $21^{\text {st }}$ CENTURY Volume 53, 2013

times during the 5-month-long semester. It means that the non-full-time students spend most of their weekends on campus.

The monthly paid $C_{h \text { direct }}$ is 30,000 HUFs (= 150 US\$) while the $C_{h \text { indirect }}$ may also reach the same amount of money or it may even be higher as the cost of repeated travelling between home and college is money-conscious. There are several other factors that are not taken into consideration (extra accommodation, extra catering, extra fees). Launching the possibility of online learning reduces the costs of distances. If students take part in online education they may save substantial part of their educational costs. According to the calculations, savings may reach $50 \%$ of their educational costs. If all their costs are reduced, the IRR becomes higher.

$$
\begin{aligned}
& \qquad \sum_{t=j+1}^{n} \frac{\left(W_{h}-W_{h-1}\right)_{t}}{(1+r)^{\zeta}}=\sum_{t=1}^{j} \frac{\left(C_{h_{-} \text {direct }}+C_{h_{-} \text {indirect }}\right)_{t}}{(1+r)^{\zeta}} \\
& \text { if } C_{h_{-} \text {indirect }} \text { decreases then } r \text { increases. }
\end{aligned}
$$

\section{Conclusions}

The study found that the ICT background of the students of the Karoly Robert College is suitable for taking online education seriously. Although the students' technological skills need to be improved by launching a temporary transitional support to provide preliminary help for students in need.

The private cost of the individual in tertiary education is not determined only by direct cost but the burden of indirect costs is also significant. In addition, the actual educational policies of the present government, the local effects of global crises (rising unemployment, declining standards of living) further deepens the hardships of everyday life.

Evidence reviewed above suggests that online education is a possible solution for decreasing the higher and higher costs of tertiary education. The traditional non full time form of education is to be converted into a new form of distance education. All necessary ingredients are at disposal for the transformation, and what's more, the offered solution of online education also carries economic values.

Based on the full results of the author's experiment the Karoly Robert College is designing and developing its own unique non-full time education system in Hungary for its future students.

\section{Acknowledgements}

The author is deeply grateful to Professor Richard M Cruse (Iowa State University, Iowa, USA), for patiently helping him through this research and for his review.

\section{References}

Allen I. E., \& Seaman, J. (2010). Class differences, online educations in the United States. The Sloan Consortium. The USA. Babson College.

Berger, G. S. (1967). Human capital and the personal distribution of income: an analytical approach. National Bureau of Economic Research. 
Laszlo F. MUCSICS. Hardships in Hungarian Tertiary Education: The Economic Role of Private Internal Rate of Return in Online Education

\author{
PROBLEMS \\ OF EDUCATION \\ IN THE $21^{\text {st }}$ CENTURY \\ Volume 53, 2013
}

Fry, R. (2012). A record one-in-five households owe a student hold debt. Pew Research. Social and Demographic Trends. Retrieved on 22 March 2013 from: http://www.pewsocialtrends. org/2012/09/26/a-record-one-in-five-households-now-owe-student-loan-debt/

Harangi, L. (2012). Több tablet, mint notebook (available only in Hungarian. Title in English: More tablets than notebooks). Retrieved on 22 March 2013 from: http://pcworld.hu/mar-tobb-tabletfogy-mint-notebook-20120823.html

Kárász, P. (2012). Hungarian students decry state sponsorship cuts and other changes. Retrieved on 22 March from: http://www.nytimes.com/2012/03/05/world/europe/hungarian-students-decry-statesponsorship-cuts.html?_r=0

Kim, P. (2012). Designing a new learning environment. Stanford university, USA, Online course, week 2, 2012 Fall.

Mashal, A. M., \& Kuddo, J. (2008). Economics of Learning style. Traditional versus E-learning. 8th Global Conference of Business and Economics. [CD].

Minh, Q. H., \& Umesh, U. N., \& Joseph, S. V. (2003). E-learning as an Emerging Entrepreneurial Enterprise in Universities and Firms. Communications of the Association for Information Systems, 2, 1-18.

Ministry for National Economy (2011). Hungary's structural reform programme 2011-2014. Retrieved on 22 March from: http://www.kormany.hu/download/b/23/20000/Hungary\%27s\%20Structural\%20 Reform.pdf

Mucsics, F. L. (2009). The efficiency of an e-learning application in teaching mathematics. ThüringischUngarisches Symposium 2009, Fachhochschule Jena, University of Applied Sciences, Germany pp. 158-164 [CD].

Polónyi, I. (2012). Felsőoktatás és gazdaság. Szép, új felsőoktatás világ Magyarországon (Tertiary education and economy. Brand, new tertiary education world in Hungary). Iskolakultúra, 2, 5056.

Tilak, J. B. G. (2006). Global Trends in Funding Higher Education. International Higher Education, 42 , 5-19.

Varga, J. (1998). Oktatás gazdaságtana (The Economics of Education) Közgazdasági Szemle Alapítvány, Budapest.

Advised by Saleh A. Alabdulkareem, King Saud University, Saudi Arabia

Received: March 01, 2013

Accepted: March 29, 2013

Laszló F. Mucsics

MSc, Senior Lecturer, Institute of Economics, Methodology and Informatics, Karoly Robert College, Mátrai út. 36., 3200 Gyöngyös, Hungary.

Phone: +36 706060390 .

E-mail: mucsicsf@karolyrobert.hu

Website: http://alia.karolyrobert.hu/cms/netalon.xml?data_id=4160 